\title{
COVID-19 trend in Bangladesh: deviation from epidemiological model and critical analysis of the possible factors
}

\section{Asif AHMED ${ }^{1 *}$ and Mohammad Mahmudur RAHMAN ${ }^{2}$}

${ }^{1}$ Biotechnology and Genetic Engineering Discipline, Khulna University, Khulna 9208, Bangladesh

${ }^{2}$ Department of Medical Biotechnology, Bangladesh University of Health Sciences, Dhaka, Bangladesh

\section{Asif AHMED}

10 Email: asif@bge.ku.ac.bd

11 ORCID: http://orcid.org/0000-0001-7401-821X

Mohammad Mahmudur RAHMAN

14 Email: maahmud@gmail.com

15 ORCID: https://orcid.org/0000-0002-1211-8642

*Correspondence:

Asif AHMED

20 asif@bge.ku.ac.bd

Ethics approval and consent to participate: not applicable

24 Availability of data and material: Secondary data used and cited in this study are publicly 25 available.

26 Competing interests: Authors declare no competing interests.

27 Funding: No funding was received for this study.

28 Authors' contributions: AA conceived the idea; AA and MMR equally contributed to the 29 manuscript and agreed to submit in its current form after necessary corrections. 
medRxiv preprint doi: https://doi.org/10.1101/2020.05.31.20118745; this version posted June 23, 2020. The copyright holder for this preprint (which was not certified by peer review) is the author/funder, who has granted medRxiv a license to display the preprint in perpetuity.

It is made available under a CC-BY-NC-ND 4.0 International license .

Abstract

2 Background: Since its first report on March 08, COVID-19 positive cases and number of deaths

3 are increasing in Bangladesh. In the first month of COVID-19 infection, incidence of daily

4 positive cases did follow the susceptible, infected and recovered (SIR) based predictions we

5 reported in April, but started to deviate in the following months. COVID-19 transmission and

6 disease progression depends on multifaceted determinants e.g. viral genetics, host immunity,

7 social distancing, co-morbidity, socio-demographic and environmental parameters. Therefore

8 deviation in confirmed cases from predicted model may appear and warrant thorough

9 investigation.

10 Methods: In this short report, we compared real data with SIR model and analyzed the possible

11 factors associated with the deviation which included preventive intervention strategies,

12 socioeconomic capabilities, climatic and meteorological indexes, acquired immunity of

13 Bangladeshi population, demographic characteristics, health indicators and food habits.

14 Results: The key factor responsible for the observed deviation was found to be the number of

15 tests performed. Having population with low median age, young age groups are being mostly

16 infected. Low prevalence of non-communicable diseases among them and strong immunity

17 compared to the elderly might have kept most of them asymptomatic with silent recovery. Warm

18 temperature, humidity and UV index of Bangladesh during this summer period might have

19 contributed to the slow progression of infection. Longer daylight mediated immunity, fresh air

20 circulations and ventilation, less population density in rural areas and certain food habits perhaps

21 helped the large number of populations to restrict the infection up to a level.

22 Conclusion: Despite all these helpful determinants in Bangladesh, person to person contact is

23 still the leading risk factor for COVID-19 transmission. Infection may increase rapidly if safe 
medRxiv preprint doi: https://doi.org/10.1101/2020.05.31.20118745; this version posted June 23, 2020. The copyright holder for this preprint (which was not certified by peer review) is the author/funder, who has granted medRxiv a license to display the preprint in perpetuity.

It is made available under a CC-BY-NC-ND 4.0 International license.

1 distance and preventive measures are not strictly followed while resuming the normal social and

2 work life. Expanding test capacity, strong collaborative action plans, strategies and

3 implementation are needed immediately to prevent catastrophe.

4

5 Keywords: COVID-19, epidemiological model, test number, temperature, heterologous

6 immunity, median age 
medRxiv preprint doi: https://doi.org/10.1101/2020.05.31.20118745; this version posted June 23, 2020. The copyright holder for this preprint (which was not certified by peer review) is the author/funder, who has granted medRxiv a license to display the preprint in perpetuity.

It is made available under a CC-BY-NC-ND 4.0 International license .

\section{$1 \quad 1$ Introduction}

2 Bangladesh is still experiencing daily rise of COVID-19 cases and deaths since its first

3 report on 08 March, 2020. As of 22 June 2020, a total of 1,15,786 confirmed cases, 46,755

4 recovery and 1,545 deaths have been recorded [1]. After its first incidence in Wuhan, China

5 in December 2019, COVID-19 spread to most of countries mostly via international

6 travelers. Bangladesh government initially started with 10 day travel ban across the country

7 from 26 March along with office and educational institutional shut down which was further

8 extended [2]. People were advised to stay home and to maintain social distance, however it

$9 \quad$ was difficult for daily wage earners and for the people staying in very dense premises [3].

10 During official leave and transport ban some unexpected mass gathering took place

11 including back and forth movement of garments workers to Dhaka, large funeral prayer and

12 crowded journey toward rural areas [1]. But overall the progression of COVID-19 in

13 Bangladesh seemed to be relatively slow.

14

15 Susceptible, infected and recovered (SIR) is a classic closed compartment epidemiological

16 model to predict disease trajectory [4]. After the rapid spread of COVID-19 many SIR and

17 modified SIR based prediction have been reported [5-8] and classic SIR model is claimed

18 to show less complexity and better prediction compared to modified models [9]. These

19 predictions are not always perfectly correct as disease progression is determined by many

20 other factors, however, such predictions help to visualize possible intervention mediated

21 outcomes and action planning can be directed accordingly. In our previous report, we used

22 SIR based prediction of COVID-19 in Bangladesh with different percentage of possible 
medRxiv preprint doi: https://doi.org/10.1101/2020.05.31.20118745; this version posted June 23, 2020. The copyright holder for this preprint (which was not certified by peer review) is the author/funder, who has granted medRxiv a license to display the preprint in perpetuity.

It is made available under a CC-BY-NC-ND 4.0 International license .

1 social distancing intervention [5]. Based on another survey and practical scenarios we

2 hypothesized around $60 \%$ social distancing could be possible in Bangladesh [10]. In

3 accordance, we showed COVID-19 in Bangladesh might reach its peak in early June and

4 would be slowed down at the end of August. The daily cumulative case number was

5 following our prediction graph very closely till late April. However, after that point

6 confirmed cases did not follow the prediction trend and fell way behind it. As COVID-19

7 incidence is being controlled by multifaceted parameters, we tried to connect the possible

8 reasons to the ongoing trend of Bangladesh. We considered demographic and climatic

9 parameters, logistic and intervention strategies taken by Bangladesh in coordination with

10 published literature to support the possible reasons.

11

12 In this short report, we investigated the deviation pattern of COVID-19 cases from our

13 previously reported SIR prediction model of Bangladesh. We also tried to explain possible

14 reasons behind this deviation and limiting factors in the light of literature. We followed

15 some key events in Bangladesh during this period as well as environmental and behavioral

16 pattern that might have influenced the outcome. We also tried to predict probable incidence

17 number if increased number of tests could be performed. In harmony with global scientific

18 data and suggestions the present and future risk factors in Bangladesh were highlighted

19 which must be addressed to limit rapid progression of COVID-19.

20

212 Methods

22 COVID-19 related data of Bangladesh viz. total test numbers, total positive cases, total

23 deaths and total recovery were retrieved on June 22, 2020 [1]. Test positive rate (\%), daily 
medRxiv preprint doi: https://doi.org/10.1101/2020.05.31.20118745; this version posted June 23, 2020. The copyright holder for this preprint (which was not certified by peer review) is the author/funder, who has granted medRxiv a license to display the preprint in perpetuity.

It is made available under a CC-BY-NC-ND 4.0 International license .

1 percent change in test numbers and daily percent change in positive cases were calculated

2 and plotted. Daily total positive case numbers were further adjusted subtracting deaths and

3 deaths plus recovery. Findings were compared with our previously reported SIR model and

4 trend of related parameters were analyzed. Global COVID-19 data were retrieved from

5 Worldometers on 22 June, 2020 [11]. GraphPad Prism v. 6.0 was used for plotting and

6 statistical analysis was done with linear regression.

$8 \quad 3 \quad$ Results

\section{$9 \quad 3.1$ Comparison of reported data and SIR model}

10 We compared previously reported SIR prediction data with real COVID-19 positive data of

11 Bangladesh from the last three months. It was observed that real cumulative cases closely

12 followed the prediction model in the initial month but later deviated from the predicted

13 numbers (Figure 1A and 1B). The predicted model with consideration of about $60 \%$

14 population under lockdown had its peak on June 06; however the real case numbers are

15 way below the prediction and still showing the rising trend shown in inset (Figure 1B).

16

17 We first looked into the relationship between daily test number and positive cases. The

18 daily test number and positive cases showed linear correlation $\left(\mathrm{R}^{2}=0.9601\right)$ over the entire

19 period (Figure 2A). Until midway positive cases were below the straight line, however with

20 increasing positive cases data tend to shift from the straight line as time progressed. We

21 also observed that in the first month although data jumped around a bit, daily percent

22 increment in test number and positive cases went hand in hand afterwards (red and blue 
medRxiv preprint doi: https://doi.org/10.1101/2020.05.31.20118745; this version posted June 23, 2020. The copyright holder for this preprint (which was not certified by peer review) is the author/funder, who has granted medRxiv a license to display the preprint in perpetuity.

It is made available under a CC-BY-NC-ND 4.0 International license .

1 line) (Figure 2B). From the beginning of May, as new number of tests got limited, slow

2 decline of these two values were observed when test positive (\%) were found to be

3 increasing (Figure 2B). During this period the test positive (\%) increased from around 10\%

4 to $20 \%$ and remained almost stable in final two weeks.

5

6 We also selected three monthly time points started from March 14 to compare SIR

7 predicted data with real cases, death adjusted cases and death with recovery adjusted cases

8 (Figure 2C). As real data points are way below the predicted value we further zoomed the

9 area to see trend of real data (Figure 2D). As SIR is close compartment model with death

10 and recovery adjusted, we also subtracted death and recovery from total cases to get similar

11 data for comparison. It showed that, from mid June death and recovery adjusted data is

12 heading downward.

13

144 Discussion

15 4.1 Possible factors behind COVID-19 incidence pattern in Bangladesh

\section{$16 \quad$ 4.1.1 Test number is a critical limiting factor}

17 To understand the prevalence and distribution pattern of COVID-19, number of tests

18 performed by a country plays critical role. Without enough testing true number of cases

19 cannot be obtained. In addition, sufficient testing is required to properly declare COVID-19

20 related deaths and recovery. In our previous report (May 26, 2020), analyzing 91

21 countries' number of tests performed per $100 \mathrm{~K}$ population data we found positive as well 
medRxiv preprint doi: https://doi.org/10.1101/2020.05.31.20118745; this version posted June 23, 2020. The copyright holder for this preprint (which was not certified by peer review) is the author/funder, who has granted medRxiv a license to display the preprint in perpetuity.

It is made available under a CC-BY-NC-ND 4.0 International license .

1 as negative correlation with positive cases and test positive (\%) respectively with statistical

2 significance [12]. Countries where limited numbers of tests were performed test positive

$3(\%)$ was comparatively higher. We reported that at that point global mean of test positive

$4 \quad(\%)$ was $9.94 \pm 1.25$ and countries with high number of tests $(>500$ tests per $100 \mathrm{~K}$

5 population) had test positive value well below $10 \%$ and countries with fewer tests $(<500$

6 tests per $100 \mathrm{~K}$ population) had average test positive rate of about $20 \%$ with extreme

7 individual value of $85.51 \%$ [11]. As of 21 June, global mean of test positive (\%) is

$8 \quad 8.47 \pm 0.88$. Countries with test numbers ranging from 500 to $5 \mathrm{~K}$ per $1 \mathrm{M}$ population have

9 average of $13.44 \%$ test positives whereas countries with test number of above $50 \mathrm{~K}$ per 1

$10 \mathrm{M}$ population has test positive (\%) value below 5. Bangladesh with 3,736 tests per $1 \mathrm{M}$

11 population, monthly data showed that daily test positive (\%) was increasing with declining

12 daily percent increase in test numbers since beginning of May (Figure 2B). After reaching

13 test positive rate around $20 \%$ the rate remained stable from early June onward. This

14 indicated that initially the test positive (\%) was getting higher due to very low number of

15 tests performed. As most of the samples tested were either contact traced known of

16 previous positive cases or people with very definite symptoms, test positive rate of $15-20 \%$

17 in Bangladesh was indicative of moderate to high infection in community. The pace of

18 daily increase in testing capacity possibly could not follow the increasing infected patient

19 numbers thus test positive (\%) tend to rise. However, the stability of test positive (\%) from

20 beginning of June is indicative of saturated test positive numbers at current test capacity.

21 However, the exact reason behind this could be multi dimensional. 
medRxiv preprint doi: https://doi.org/10.1101/2020.05.31.20118745; this version posted June 23, 2020. The copyright holder for this preprint (which was not certified by peer review) is the author/funder, who has granted medRxiv a license to display the preprint in perpetuity.

It is made available under a CC-BY-NC-ND 4.0 International license .

1 To better understand the relationship we tabulated number of tests, test positive (\%) and

2 population density per $\mathrm{km}^{2}$ of some representative countries (Table 1 ). It is evident that

3 with increasing test capacity, test positive rate decreased. One exception here is Sweden

4 where official lock down or social distancing were not in place. It was also observed that

5 although population density of Sweden is low, due to poor social distancing the virus could

6 infect people very easily. Rather than direct effect of population density on test positive

7 rate, it was more important at what extent direct person to person contact were restricted.

8

In the initial stage, Bangladesh Institute of Epidemiology, Disease Control and Research (IEDCR) alone collected and performed PCR test of suspected samples. Gradually test capacity was extended to public and private hospitals, universities, research organizations around the country which is at present more than 50 in number. Bangladesh is one of the low investing countries in health sector (health expenditure of 36.28 USD per capita) [13], thus the extension of test center and recruitment and training of expertise was relatively slow and still way below the need compared to large number of populations. Especially with the increasing rate of infection this can be vital limiting factor to know real case scenario in Bangladesh. These extended centers however are mainly in divisional headquarters or in large cities, where rural people staying away from the facility had difficulty to test as inter-city transport was closed. This has resulted some samples to become non usable and some false negative as samples might have been deteriorated due to longer transport and improper sample collection. We also identified that due to social non cooperation toward the COVID-19 positive or health care practitioners, many suspected individual were reluctant to give sample due to social fear. Although government hot line is 
medRxiv preprint doi: https://doi.org/10.1101/2020.05.31.20118745; this version posted June 23, 2020. The copyright holder for this preprint (which was not certified by peer review) is the author/funder, who has granted medRxiv a license to display the preprint in perpetuity.

It is made available under a CC-BY-NC-ND 4.0 International license .

1 open for all, many people had dissatisfactory experience calling for sample collection. Lack

2 of management, long queue, waiting time in sample collection and test centers and delayed

3 result also had negative impact, fear and rejection tendency among test seekers. These

4 factors altogether had impact on uniform and broad data collection raising reliability issues

5 on reported case numbers so far.

7 We further speculated possible incidence number as of 21 June if the test numbers in

8 Bangladesh were close to high capacity testing countries (Table 2). To do this we

9 calculated two possible scenarios where $50 \mathrm{~K}$ and $100 \mathrm{~K}$ tests per $1 \mathrm{M}$ population were

10 performed as of 21 June. If 5 to $10 \%$ test positives (\%) were to be observed, approximately

110.4 to 0.8 million incidences could have been recorded. To achieve this Bangladesh had to

12 perform around 13 times more tests compared to the tests done at present moment. This

13 indicated that as Bangladesh are performing very low number of tests, it is hardly possible

14 to achieve trend curve reaching peak and declining even though that amount of positives

15 are present in community. It is also worth mentioning that limited test number can strongly

16 influence the confirmation of death due to COVID-19 affecting true death count. It also can

17 affect documentation of recovery numbers due to lack of subsequent testing of all

18 confirmed positives.

$19 \quad$ 4.1.2 Population median age and obesity prevalence

20 In our previous report we also found that countries with high median age showed strong

21 association with COVID-19 case fatality rate [12]. This was mainly due to prevalence of

22 non communicable diseases as contributing factor for comorbidity and reduced immunity 
medRxiv preprint doi: https://doi.org/10.1101/2020.05.31.20118745; this version posted June 23, 2020. The copyright holder for this preprint (which was not certified by peer review) is the author/funder, who has granted medRxiv a license to display the preprint in perpetuity.

It is made available under a CC-BY-NC-ND 4.0 International license .

1 of elderly people. Bangladesh has median age of 27.90 years [14], with less elderly people.

2 This could be one reason that young age group being dominant in the society are the most

3 infected among all (55\% belong to 21 to 40 years age group) [15]. Their inherent strong

4 immunity might be a reason for silent infection and recovery with mild or even no

5 symptoms at all. As of 31 May 2020 case fatality rate of Bangladesh is $1.38 \%$ which is

6 below the global average of $4.26 \pm 0.38$ which could be due to less proportion of elderly in

7 Bangladesh compared to the countries with high median age where case fatality climbed

8 above $10 \%$. Prevalence of obesity is linked to non communicable diseases which is low in

9 Bangladeshi adult population (3.6\%) [16]. Thus low obesity prevalence might have helped

10 to minimize the co morbidity related complexity in Bangladeshi COVID-19 infected

11 people.

\section{$12 \quad 4.1 .3 \quad$ Environmental parameters}

13 Scientists are having a wave of optimism that warmer weather might improve COVID-19

14 scenario [17]. Temperature, absolute humidity, relative humidity (RH), sunlight, ambient

15 air flow, and altitudes were mostly studied parameters [18,19]. Respiratory viruses usually

16 follow seasonal pattern, preferring either winter or summer, whereas some of them prefer to

17 be year around virus [20]. Information regarding SARS-CoV-2 is still insufficient to label

18 its seasonality; however, known other human corona viruses had shown clear preferences to

19 winter. COVID-19 data so far showed temperate regions as the prevalence hot zone, but

20 tropical areas are not completely out of the list. In one particular season incidence peak or

21 hot spot may vary from virus to virus and usually avoid overlapping. Temperature and

22 humidity determine the route of transmission and viral stability both in indoor and outdoor 
medRxiv preprint doi: https://doi.org/10.1101/2020.05.31.20118745; this version posted June 23, 2020. The copyright holder for this preprint (which was not certified by peer review) is the author/funder, who has granted medRxiv a license to display the preprint in perpetuity.

It is made available under a CC-BY-NC-ND 4.0 International license .

1 settings. Cold and dry weather dominate transmission via aerosol and small droplets

2 whereas hot and humid weather facilitate transmission via fomites. Temperature above

$3 \quad 30^{\circ} \mathrm{C}$ showed to block aerosol mediated Influenza virus transmission at variable $\mathrm{RH}$, but

4 contact mode transmission was still possible [21]. Surface stability and viability of SARS-

$5 \mathrm{CoV}$ was shown to be lost at high temperature and high RH [22]. Bangladesh with monthly

6 high temperature above $30^{\circ} \mathrm{C}$ and average temperature above $25^{\circ} \mathrm{C}$ from March to October

7 may have reduced aerosol mediated viral transmission slowing community level infection

8 rate.

9

10 UV index and air pollution may also play contributing role in viral transmission.

11 Anthropogenic pollutants and microbes share common mechanism to confer immune

12 deficiency [23]. These pollutants prepare the ground for COVID-19 like pandemic and

13 further worsen the outbreak. Air particulate materials were found to be positively

14 associated with COVID-19 incidence. Due to government imposed travel ban, reduced

15 industrial effect air particulate emission was also low for the last two months which might

16 have helped to reduce particulate material mediated virus transmission. Bangladesh has

17 very high UV index during summer months with average of 10 or above with increased

18 daylight hours [24]. UV index and daylight is related to ozone concentration which was

19 found to reduce viability of viruses and COVID-19 transmission in a study conducted in

20 Chinese cities [25]. In Bangladesh, ozone level in summer daylight may have helped to

21 reduce viability of the viruses in environment [26]. Sunlight exposure which is also related

22 to vitamin D production and immunity had helped to provide population level immunity to

23 fight COVID-19 in Bangladesh [27]. Besides, with official leave, many people left capital 
medRxiv preprint doi: https://doi.org/10.1101/2020.05.31.20118745; this version posted June 23, 2020. The copyright holder for this preprint (which was not certified by peer review) is the author/funder, who has granted medRxiv a license to display the preprint in perpetuity.

It is made available under a CC-BY-NC-ND 4.0 International license .

1 city to stay with families in rural areas, where factors like low population density, air

2 velocity, and sunlight exposure were helpful to restrict virus transmission.

\subsubsection{Heterologous immunity and food habit}

4 Heterologous immunity, a form of cross reactivity is acquired from previously challenged

5 unrelated microorganisms providing wider vaccine induced effectiveness and natural

6 immunity against new infections [28,29]. Memory CD8+ T cells can help to detect newly

7 infected viruses, but due to strain variation in RNA viruses less effective immunity is

8 observed in human and in some cases show immune pathology[30]. Bangladesh is a

9 densely populated country and people are exposed to different microorganisms during their

10 lifetime, thus highly likely acquire heterologous immunity from natural infections. One

11 study with cholera vaccination in Bangladesh showed natural immunity were long lasting

12 compared to the oral vaccine [31]. In another study, Bangladeshi children were found to

13 express more effector T cell activity compared to American children, supporting the

14 'hygiene hypothesis' [32]. According to this hypothesis early exposure to infectious agents

15 may provide better immunity and in contrast lack of exposure may lead to allergies and

16 autoimmune diseases. This also explains in part, reduced COVID-19 incidence in

17 Bangladesh could be due to childhood acquired immunity against a variety of organisms.

18 Co-infection of viruses is another aspect where one or more viruses may compete with

19 another minimizing the virulence of the other [33]. Viral co-infection was reported in

20 COVID-19 [34,35] and in Bangladesh as viral co-infection was observed in case of other

21 viruses [36], co-infection of other respiratory viruses may have inhibitory effect on

22 COVID-19 transmission and virulence. Food which boosts immune systems e.g. seasonal 
medRxiv preprint doi: https://doi.org/10.1101/2020.05.31.20118745; this version posted June 23, 2020. The copyright holder for this preprint (which was not certified by peer review) is the author/funder, who has granted medRxiv a license to display the preprint in perpetuity.

It is made available under a CC-BY-NC-ND 4.0 International license .

1 fruits, vegetables and spices could also play a positive role in slowing COVID-19 in

2 Bangladesh.

\section{$4 \quad 5$ Conclusion and outlook}

5 Although many factors seemed to help Bangladesh to an extent, other factors like

6 population density, urban population percentage and negligence toward health precautions

$7 \quad$ still pose high risk of person to person disease transmission especially when offices and

8 transport will be open. Climatic parameters may slow down COVID-19 transmission

9 pattern and duration, however considering the size of pandemic its effect is modest [37].

10 Countries in both temperate and tropical regions must prepare for the possibility of severe

11 outbreak; however, climatic variation will help to determine the local endemic cycle and

12 seasonal peak. Step by step precautions are necessary to reduce sudden spike in infection

13 number. Coming winter may face a second wave, so extended measures should be in place

14 to contain the COVID-19 in Bangladesh. Public health policy and strategies need to be

15 carefully adjusted considering these aspects to slow down the pandemic pace so that

16 effective medical facilities can be provided to maximum possible people using available

17 resources.

18

19 References

20 1. COVID-19 pandemic in Bangladesh. https://en.wikipedia.org/wiki/COVID-

21 19_pandemic_in_Bangladesh. Accessed 21 June 2020 
medRxiv preprint doi: https://doi.org/10.1101/2020.05.31.20118745; this version posted June 23, 2020. The copyright holder for this preprint (which was not certified by peer review) is the author/funder, who has granted medRxiv a license to display the preprint in perpetuity.

It is made available under a CC-BY-NC-ND 4.0 International license .

12 . Govt imposes 10-day ban on public transports from March 26

2

3 https:/www.newagebd.net/article/103078/govt-imposes-10-day-ban-on-publictransports-from-march-26.

3. Coronavirus: In dense Bangladesh, social distancing a tough task. https://www.aljazeera.com/news/2020/03/coronavirus-dense-bangladesh-socialdistancing-tough-task-200320103733470.html.

4. Kermack, W.O., McKendrick, A.G.: A contribution to the mathematical theory of epidemics. Proceedings of the Royal Society A 115(772) (1927). doi:https://doi.org/10.1098/rspa.1927.0118

5. Rahman, M.M., Ahmed, A., Hossain, K.M., Haque, T., Hossain, M.A.: Impact of control strategies on COVID-19 pandemic and the SIR model based forecasting in Bangladesh. medRxiv preprint (2020). doi:10.1101/2020.04.19.20071415

6. Islam, M.S., Ira, J.I., Kabir, K.M.A., Kamrujjaman, M.: COVID-19 Epidemic Compartments Model and Bangladesh. Preprints (2020). doi:doi: 10.20944/preprints202004.0193.v2

7. Wangping, J., Ke, H., Yang, S., Wenzhe, C., Shengshu, W., Shanshan, Y.et al. : Extended SIR Prediction of the Epidemics Trend of COVID-19 in Italy and Compared With Hunan, China. Frontiers in medicine 7, 169 (2020). doi:10.3389/fmed.2020.00169

8. Giordano, G., Blanchini, F., Bruno, R., Colaneri, P., Di Filippo, A., Di Matteo, A.et al. : Modelling the COVID-19 epidemic and implementation of population-wide interventions in Italy. Nature Medicine (2020). doi:10.1038/s41591-020-0883-7 
medRxiv preprint doi: https://doi.org/10.1101/2020.05.31.20118745; this version posted June 23, 2020. The copyright holder for this preprint (which was not certified by peer review) is the author/funder, who has granted medRxiv a license to display the preprint in perpetuity.

It is made available under a CC-BY-NC-ND 4.0 International license .

1 9. Roda, W.C., Varughese, M.B., Han, D., Li, M.Y.: Why is it difficult to accurately predict the COVID-19 epidemic? Infectious Disease Modelling 5, 271-281 (2020). doi:10.1016/j.idm.2020.03.001

10. Haque, T., Hossain, K.M., Bhuiyan, M.M.R., Ananna, S.A., Chowdhury, S.H., Ahmed, A.et al. : Knowledge, attitude and practices (KAP) towards COVID-19 and

11. Worldometers: COVID-19 Coronavirus pandemic. https://www.worldometers.info/coronavirus/ (2020). Accessed June 222020

12. Ahmed, A., Haque, T., Rahman, M.M.: Lifestyle acquired immunity, decentralized intelligent infrastructures and revised healthcare expenditures may limit pandemic catastrophe: a lesson from COVID-19. medRxiv preprint (2020). doi:10.1101/2020.05.23.20111104

13. WORLDBANK: World Bank open data. https://data.worldbank.org/ (2020). Accessed May 012020

14. Country comparison-median age. https://www.cia.gov/library/publications/resources/the-worldfactbook/fields/343rank.html. Accessed May 312020

15. Deaths by age. https://www.iedcr.gov.bd/. Accessed May 312020

16. WHO: Prevalence of obesity among adults, $\mathrm{BMI} \geq 30$, age-standardized: Estimates by country. https://apps.who.int/gho/data/node.main.A900A?lang=en (2017). Accessed May 062020 
medRxiv preprint doi: https://doi.org/10.1101/2020.05.31.20118745; this version posted June 23, 2020. The copyright holder for this preprint (which was not certified by peer review) is the author/funder, who has granted medRxiv a license to display the preprint in perpetuity.

It is made available under a CC-BY-NC-ND 4.0 International license .

1 17. Wang, J., Tang, K., Feng, K., Lin, X., Lv, W., Chen, K.X.et al. : High Temperature and

High Humidity Reduce the Transmission of COVID-19. SSRN (2020). doi:10.2139/ssrn.3551767

18. Ahmadi, M., Sharifi, A., Dorosti, S., Jafarzadeh Ghoushchi, S., Ghanbari, N.: Investigation of effective climatology parameters on COVID-19 outbreak in Iran. Science of The Total Environment 729, 138705 (2020). doi:https://doi.org/10.1016/j.scitotenv.2020.138705

19. Feng, Y., Marchal, T., Sperry, T., Yi, H.: Influence of wind and relative humidity on the social distancing effectiveness to prevent COVID-19 airborne transmission: A numerical study. Journal of aerosol science, 105585 (2020). doi:10.1016/j.jaerosci.2020.105585

20. Moriyama, M., Hugentobler, W.J., Iwasaki, A.: Seasonality of Respiratory Viral Infections. Annual review of virology (2020). doi:10.1146/annurev-virology012420-022445

21. Lowen, A.C., Steel, J., Mubareka, S., Palese, P.: High temperature (30 degrees C) blocks aerosol but not contact transmission of influenza virus. Journal of virology 82(11), 5650-5652 (2008). doi:10.1128/JVI.00325-08

22. Chan, K.H., Peiris, J.S., Lam, S.Y., Poon, L.L., Yuen, K.Y., Seto, W.H.: The Effects of Temperature and Relative Humidity on the Viability of the SARS Coronavirus. Advances in virology 2011, 734690 (2011). doi:10.1155/2011/734690

23. Tsatsakis, A., Petrakis, D., Nikolouzakis, T.K., Docea, A.O., Calina, D., Vinceti, M.et al. : COVID-19, an opportunity to reevaluate the correlation between long-term effects of anthropogenic pollutants on viral epidemic/pandemic events and 
medRxiv preprint doi: https://doi.org/10.1101/2020.05.31.20118745; this version posted June 23, 2020. The copyright holder for this preprint (which was not certified by peer review) is the author/funder, who has granted medRxiv a license to display the preprint in perpetuity.

It is made available under a CC-BY-NC-ND 4.0 International license .

prevalence. Food and chemical toxicology : an international journal published for the British Industrial Biological Research Association 141, 111418 (2020). doi:10.1016/j.fct.2020.111418

24. Monthly weather forecast and climate, Dhaka, Bangladesh https://www.weatheratlas.com/en/bangladesh/dhaka-climate\#uv index.

25. Yao, M., Zhang, L., Ma, J., Zhou, L.: On airborne transmission and control of SARSCov-2. The Science of the total environment 731, 139178 (2020). doi:10.1016/j.scitotenv.2020.139178

26. Rahman, M.M., Mahamud, S., Thurston, G.D.: Recent spatial gradients and time trends in Dhaka, Bangladesh, air pollution and their human health implications. Journal of the Air \& Waste Management Association 69(4), 478-501 (2019). doi:10.1080/10962247.2018.1548388

27. Grant, W.B., Lahore, H., McDonnell, S.L., Baggerly, C.A., French, C.B., Aliano, J.L.et al. : Evidence that Vitamin D Supplementation Could Reduce Risk of Influenza and COVID-19 Infections and Deaths. Nutrients 12(4) (2020). doi:10.3390/nu12040988 28. Agrawal, B.: Heterologous Immunity: Role in Natural and Vaccine-Induced Resistance to Infections. Frontiers in immunology 10, 2631 (2019). doi:10.3389/fimmu.2019.02631

29. Welsh, R.M., Che, J.W., Brehm, M.A., Selin, L.K.: Heterologous immunity between viruses. Immunological reviews 235(1), 244-266 (2010). doi:10.1111/j.01052896.2010.00897.x 
medRxiv preprint doi: https://doi.org/10.1101/2020.05.31.20118745; this version posted June 23, 2020. The copyright holder for this preprint (which was not certified by peer review) is the author/funder, who has granted medRxiv a license to display the preprint in perpetuity.

It is made available under a CC-BY-NC-ND 4.0 International license .

1 30. Sharma, S., Thomas, P.G.: The two faces of heterologous immunity: protection or

2

3

$$
\text { immunopathology. Journal of leukocyte biology 95(3), 405-416 (2014). }
$$
doi:10.1189/jlb.0713386

31. Alam, M.M., Riyadh, M.A., Fatema, K., Rahman, M.A., Akhtar, N., Ahmed, T.et al. : Antigen-Specific Memory B-Cell Responses in Bangladeshi Adults after One- or Two-Dose Oral Killed Cholera Vaccination and Comparison with Responses in Patients with Naturally Acquired Cholera. Clinical and Vaccine Immunology 18(5), 844 (2011). doi:10.1128/CVI.00562-10

32. Wagar, L.E., Bolen, C.R., Sigal, N., Lopez Angel, C.J., Guan, L., Kirkpatrick, B.D.et al. : Increased T Cell Differentiation and Cytolytic Function in Bangladeshi Compared to American Children. Frontiers in immunology 10, 2239 (2019). doi:10.3389/fimmu.2019.02239

33. Kumar, N., Sharma, S., Barua, S., Tripathi, B.N., Rouse, B.T.: Virological and Immunological Outcomes of Coinfections. Clinical microbiology reviews 31(4) (2018). doi:10.1128/CMR.00111-17

34. Cuadrado-Payan, E., Montagud-Marrahi, E., Torres-Elorza, M., Bodro, M., Blasco, M., Poch, E.et al. : SARS-CoV-2 and influenza virus co-infection. Lancet 395(10236), e84 (2020). doi:10.1016/S0140-6736(20)31052-7

35. Wu, X., Cai, Y., Huang, X., Yu, X., Zhao, L., Wang, F.et al. : Co-infection with SARSCoV-2 and Influenza A Virus in Patient with Pneumonia, China. Emerging infectious diseases 26(6), 1324-1326 (2020). doi:10.3201/eid2606.200299

36. Bhuyan, G.S., Hossain, M.A., Sarker, S.K., Rahat, A., Islam, M.T., Haque, T.N.et al. : Bacterial and viral pathogen spectra of acute respiratory infections in under-5 
medRxiv preprint doi: https://doi.org/10.1101/2020.05.31.20118745; this version posted June 23, 2020. The copyright holder for this preprint (which was not certified by peer review) is the author/funder, who has granted medRxiv a license to display the preprint in perpetuity.

It is made available under a CC-BY-NC-ND 4.0 International license .

children in hospital settings in Dhaka city. PloS one 12(3), e0174488 (2017). doi:10.1371/journal.pone.0174488

3 37. Baker, R.E., Yang, W., Vecchi, G.A., Metcalf, C.J.E., Grenfell, B.T.: Susceptible

4 supply limits the role of climate in the early SARS-CoV-2 pandemic. Science (2020). doi:10.1126/science.abc2535 
1 Table 1: Representative comparison of tests per $1 \mathrm{M}$ population, test positive (\%) and

2 population density per $\mathrm{km}^{2}$ of some countries along with Bangladesh

\begin{tabular}{|c|c|c|c|}
\hline Country & Tests/1M population & Test Positive (\%) & Population Density/km ${ }^{2}$ \\
\hline Netherlands & 30,192 & 9.59 & 511 \\
\hline Sweden & 38,193 & 14.53 & 25 \\
\hline Italy & 82,436 & 4.78 & 205 \\
\hline USA & 86,090 & 8.27 & 35 \\
\hline Singapore & 98,508 & 7.31 & 933 \\
\hline Spain & 110,426 & 5.68 & 274 \\
\hline UK & 116,241 & 3.86 & 8.82 \\
\hline Russia & 116,481 & 3.44 & 135 \\
\hline UAE & 307,270 & 1.48 & 1239 \\
\hline Bangladesh & 3,642 & 18.14 & \\
\hline
\end{tabular}

3 [Data retrieved from Worldometers on June 22, 2020]

4 Table 2: Tests per $1 \mathrm{M}$ in Bangladesh as of 21 June and probable outcome if tests were

5 performed at higher rate

\begin{tabular}{|c|c|c|c|}
\hline Test/1M & Number of tests & Positive case & Test positive (\%) \\
\hline 3736 & $6,15,164$ & $1,12,306$ & 18.26 \\
\hline \multicolumn{3}{|c|}{ Probable tests/1M and approximate outcomes } \\
\hline 50,000 & $82,32,922$ & $8,23,292$ & if 10 \\
& & $4,11,646$ & if 5 \\
\hline 100,000 & $1,64,65,845$ & $8,23,292$ & if 5 \\
\hline
\end{tabular}

6 
A
B

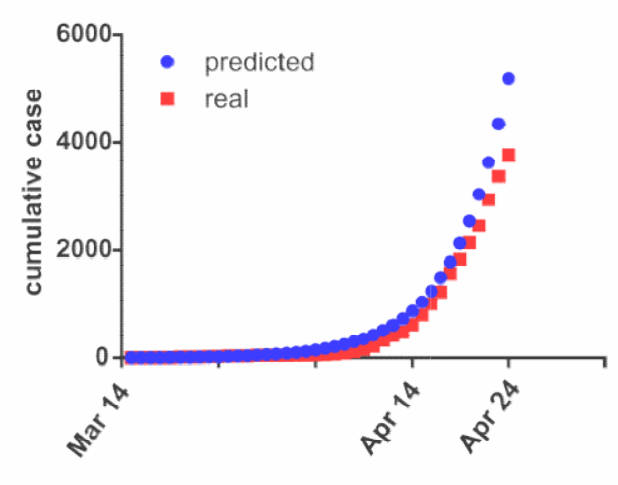

Figure 1

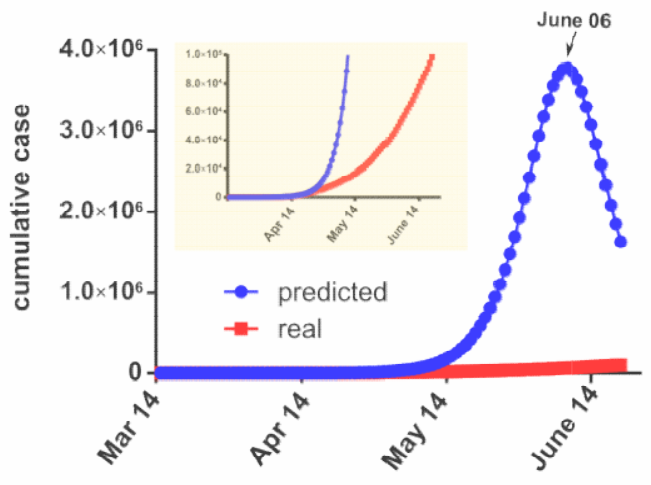

A

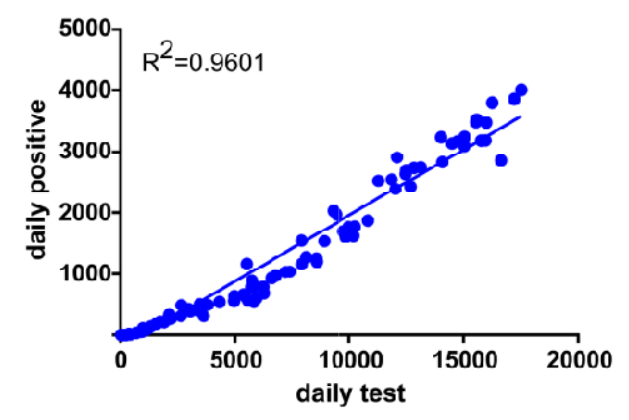

C

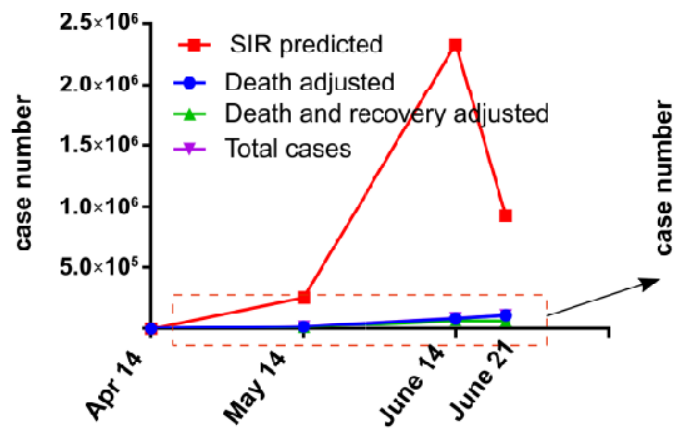

B

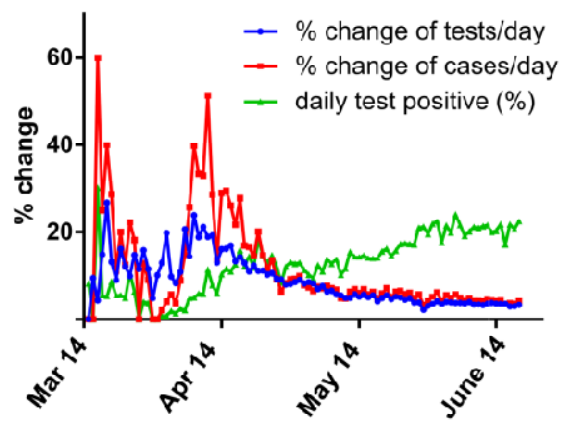

D

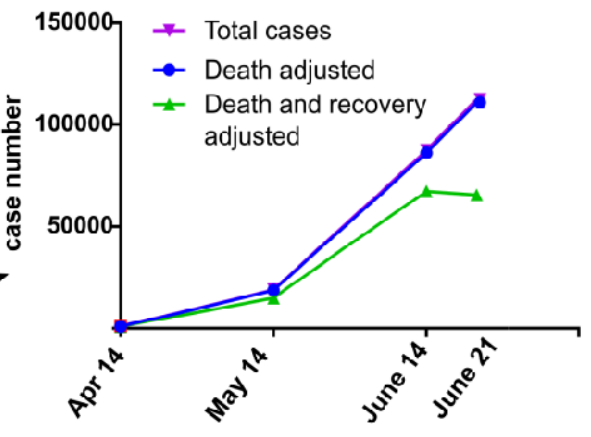


medRxiv preprint doi: https://doi.org/10.1101/2020.05.31.20118745; this version posted June 23, 2020. The copyright holder for this preprint (which was not certified by peer review) is the author/funder, who has granted medRxiv a license to display the preprint in perpetuity.

It is made available under a CC-BY-NC-ND 4.0 International license.

\section{Figure legend}

2 Figure 1: Graphical representation of COVID-19 SIR model and deviation in real data in

3 Bangladesh. (A), previously reported SIR model with predicted and real cumulative cases from

4 March 14 to April 24, 2020 (adapted from [5]); (B), same model compared extended up to June 21,

52020 ; the inset shows trend of real cases with zoomed y axis data.

6

7 Figure 2: Real and SIR model data comparison. (A), daily test vs. daily positive case with linear

8 regression fit $\left(\mathrm{R}^{2}=0.9601\right)$; $(\mathrm{B})$, daily percent change in test number and daily percent change in

9 new cases are plotted with daily test positive (\%) and (C), SIR predicted cases, real total cases,

10 death adjusted cases and death with recovery adjusted cases were plotted in three monthly interval

11 data point, and (D), part of Fig 2C (red dot rectangle) was further zoomed in to get better view.

12 GraphPad Prism v. 6.0 was used to plot graphs and compiled in Inkscape v. 0.92.

13

14

15

16

17

18

19

20

21

22

23

24

25

26 
medRxiv preprint doi: https://doi.org/10.1101/2020.05.31.20118745; this version posted June 23, 2020. The copyright holder for this preprint (which was not certified by peer review) is the author/funder, who has granted medRxiv a license to display the preprint in perpetuity.

It is made available under a CC-BY-NC-ND 4.0 International license.

\section{Highlights}

2 1. Limited number of tests compared to large population was the key reason for possible low daily positive cases reported in Bangladesh.

2. Controlled interventions viz. official leave; transport ban and social distancing had helped initially to slow down the transmission.

3. Warm weather, high humidity and UV index, sunlight mediated immunity, fresh air circulations, low pollutions, food habit and heterologous immunity might have reduced the transmission capabilities of SARS-CoV-2.

9

4. Having large number of young people with strong immunity might have kept most contain further transmission. 
A

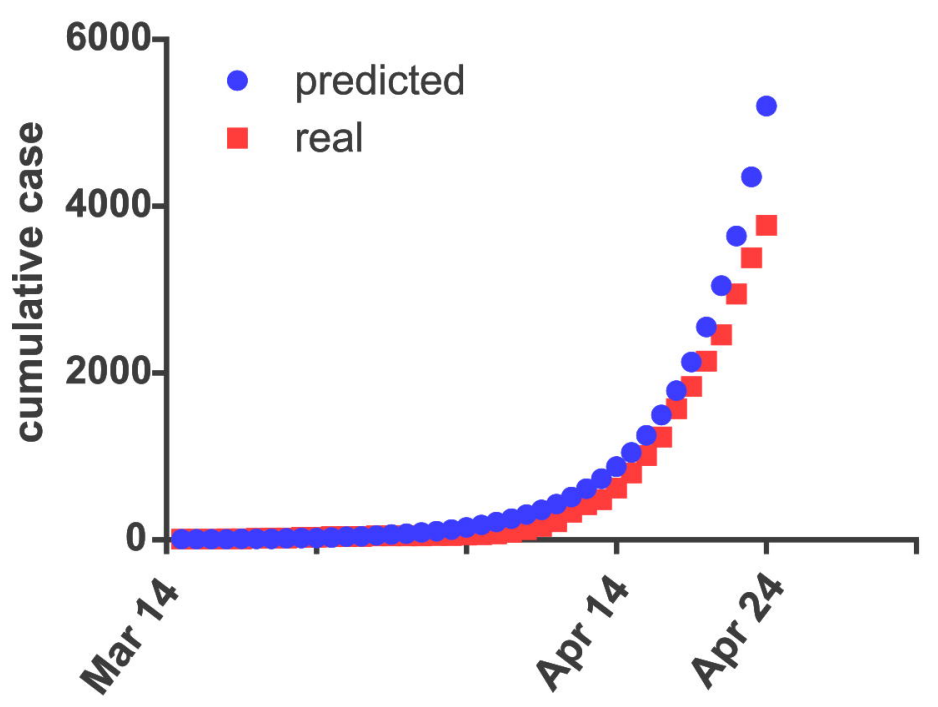

B

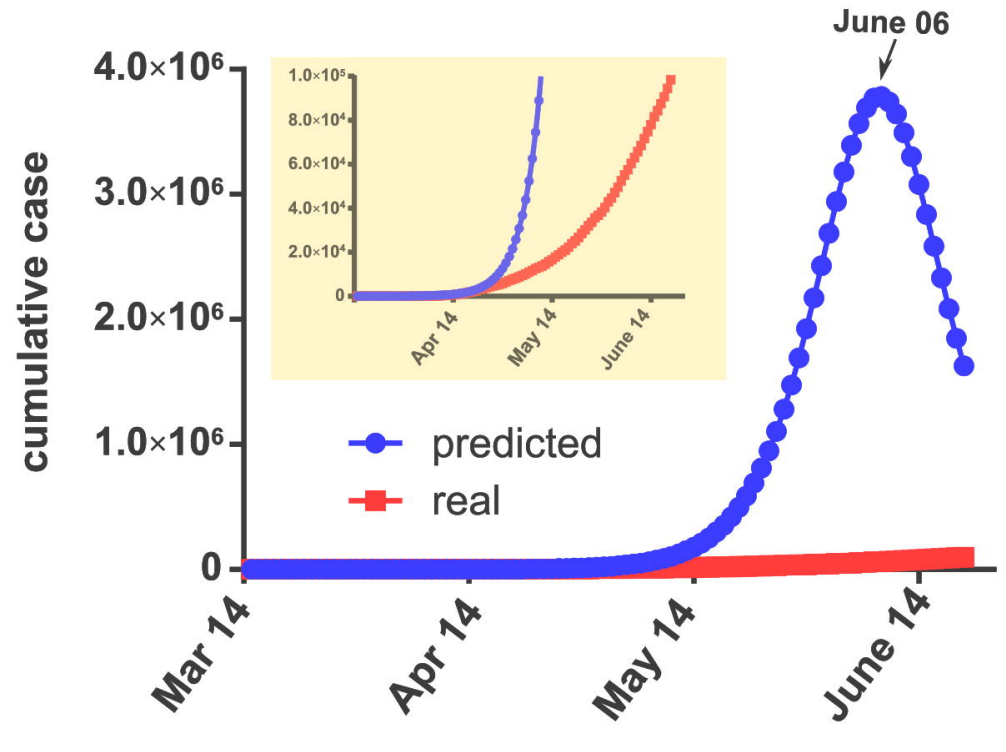


A

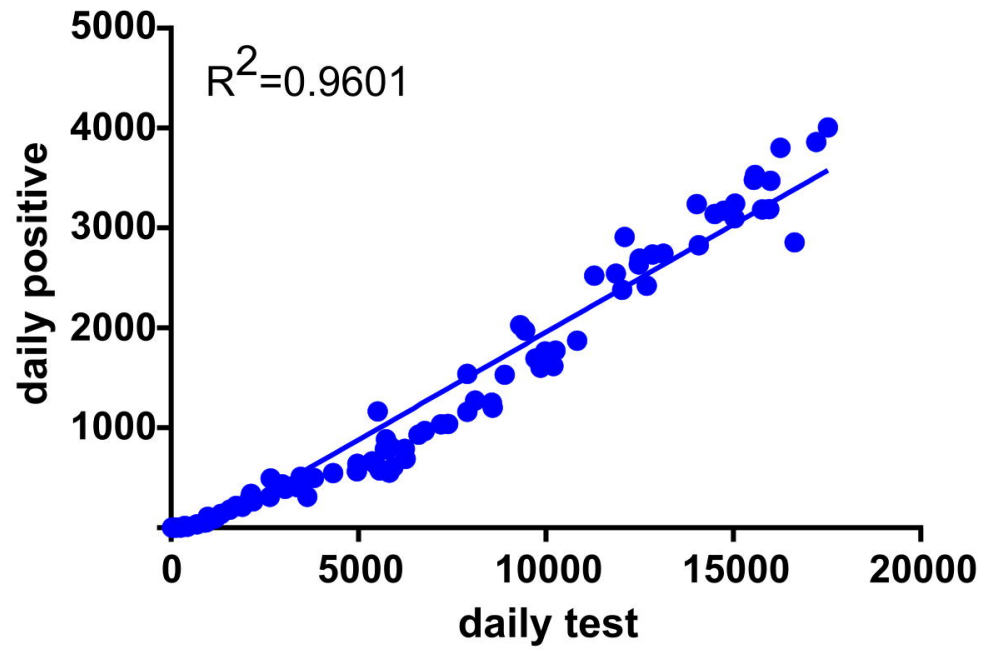

C

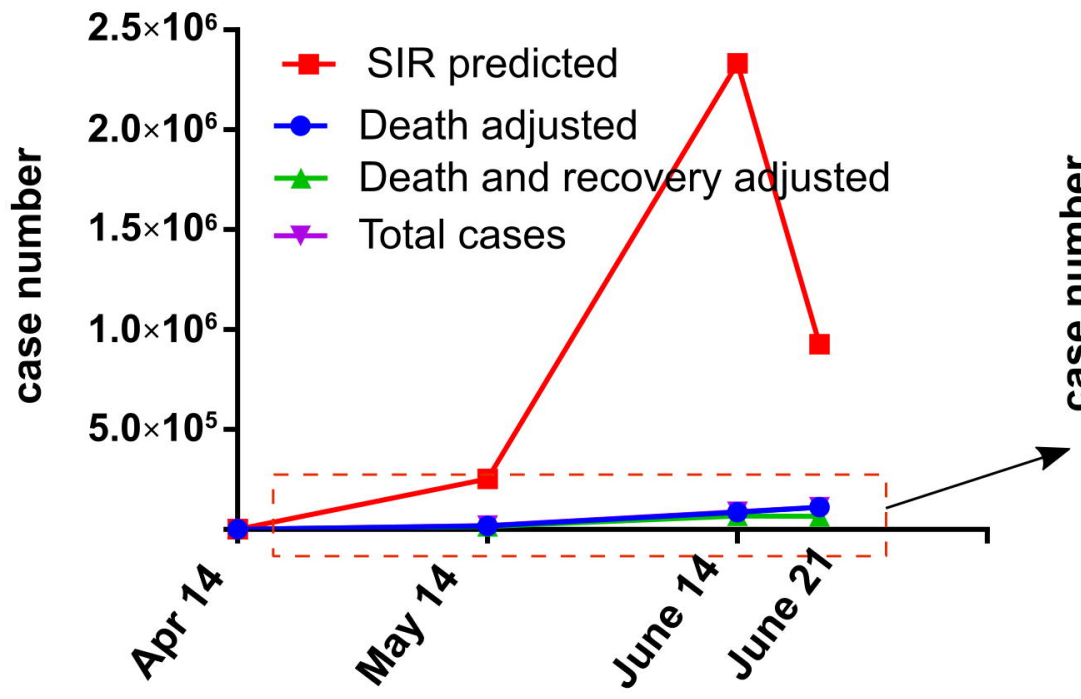

B

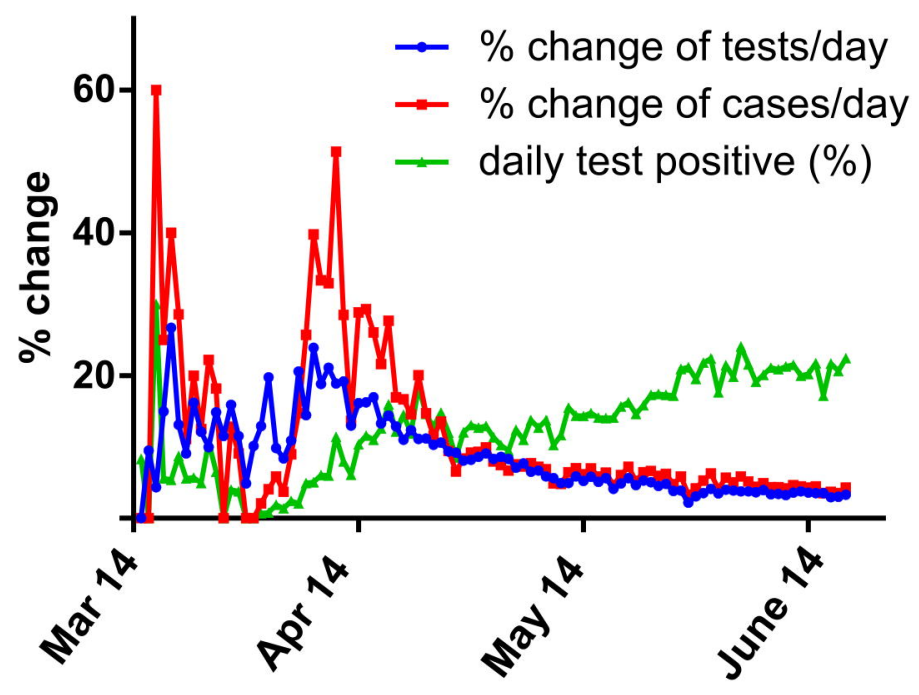

D

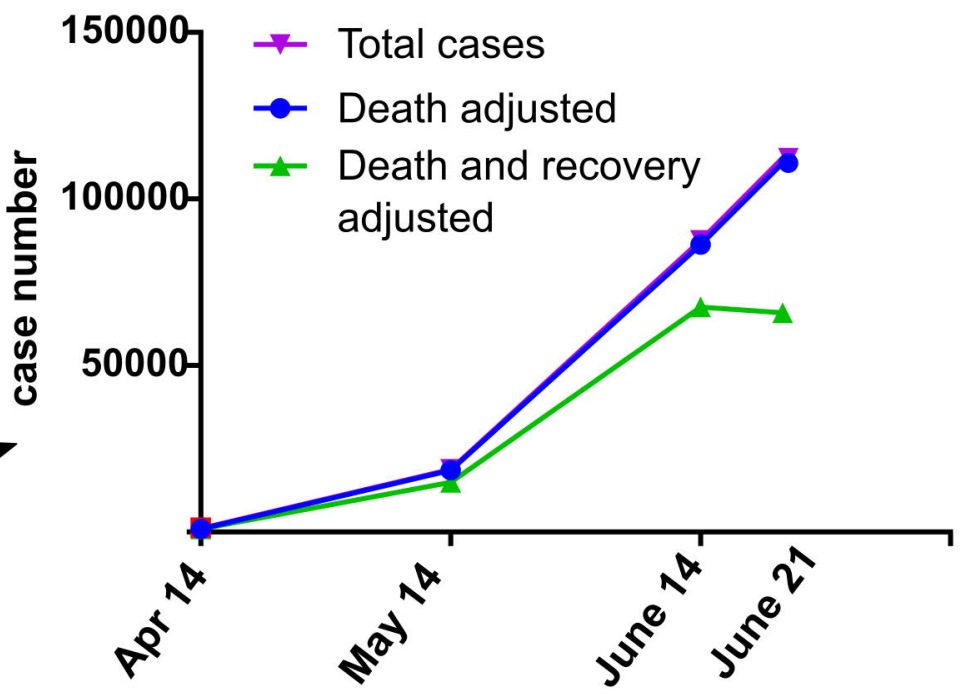

